\title{
Sequential Expression of Bacterial Virulence and Plant Defense Genes During Infection of Tomato with Clavibacter michiganensis subsp. michiganensis
}

\author{
L. Chalupowicz, M. Cohen-Kandli, O. Dror, R. Eichenlaub, \\ K.-H. Gartemann, G. Sessa, I. Barash, and S. Manulis-Sasson
}

First, second, third, and eighth authors: Department of Plant Pathology and Weed Research, ARO, the Volcani Center, Bet Dagan, Israel; first, second, sixth, and seventh authors: Department of Plant Sciences, Tel Aviv University, Israel; and fourth and fifth authors: Fakultät für Biologie, Gentechnologie/Mikrobiologie, Universität Bielefeld, Germany.

Accepted for publication 21 October 2009.

\begin{abstract}
Chalupowicz, L., Cohen-Kandli, M., Dror, O., Eichenlaub, R., Gartemann, K.-H., Sessa, G., Barash, I., and Manulis-Sasson, S. 2010. Sequential expression of bacterial virulence and plant defense genes during infection of tomato with Clavibacter michiganensis subsp. michiganensis. Phytopathology 100:252-261.

The molecular interactions between Clavibacter michiganensis subsp. michiganensis and tomato plant were studied by following the expression of bacterial virulence and host-defense genes during early stages of infection. The $C$. michiganensis subsp. michiganensis genes included the plasmid-borne cellulase (celA) and the serine protease (pat-1), and the serine proteases $\operatorname{chpC}$ and $p p a A$, residing on the chp/tomA pathogenicity island (PAI). Gene expression was measured following tomato inoculation with $C m m 382$ (wild type), Cmm100 (lacking the plasmids pCM1

and pCM2), and Cmm27 (lacking the PAI). Transcriptional analysis revealed that celA and pat- 1 were significantly induced in $\mathrm{Cmm} 382$ at initial 12 to $72 \mathrm{~h}$, whereas $\operatorname{chpC}$ and $p p a A$ were highly expressed only 96 $\mathrm{h}$ after inoculation. Interdependence between the expression of chromosomal and of plasmid-located genes was revealed: expression of celA and pat- 1 was substantially reduced in the absence of the chp/tomA PAI, whereas $\operatorname{chpC}$ and $p p a A$ expressions were reduced in the absence of the virulence plasmids. Transcription of chromosomal genes involved in cell wall degradation (i.e., pelAl, $c e l B, x y s A$, and $x y s B$ ), was also induced at early stages of infection. Expression of the host-defense genes, chitinase class II and pathogenesis-related protein-5 isoform was induced in the absence of the PAI at early stages of infection, suggesting that PAIlocated genes are involved in suppression of tomato basal defenses.
\end{abstract}

The plant-pathogenic bacterium Clavibacter michiganensis subsp. michiganensis is a gram-positive actinomycete and is the causal agent of tomato (Solanum lycopersicum) bacterial wilt, an economically important disease worldwide $(8,37)$. A noticeable early symptom of the disease is a unilateral wilting of leaves, which culminates with the development of canker lesions on tomato stems, and tissue disintegration that leads to plant death (37). The interaction of $C$. michiganensis subsp. michiganensis with tomato can be divided into two stages: (i) an endophytic stage that leads to colonization of the tomato xylem by a large $C$. michiganensis subsp. michiganensis population, and (ii) a symptom-inducing stage (17). Two plasmids, pCM1 and pCM2, which were originally discovered in the wild-type strain NCPPB382, are essential for virulence (26). Loss of either of these two plasmids reduces virulence, whereas simultaneous loss of both plasmids eliminates virulence but retains the endophytic colonization of the plant by the pathogen $(17,26)$. pCM1 encodes for CelA, a secreted cellulase with endo- $\beta$-1,4-glucanase activity (22), and pCM2 encodes for Pat-1, a putative serine protease (10). CelA protein contains catalytic and binding domains that show extensive similarity to other bacterial cellulases, and a unique third domain with a weak similarity to $\alpha$-expansins from plants

Corresponding author: S. Manulis-Sasson

E-mail address: shulam@volcani.agri.gov.il

* The $\boldsymbol{e}$-Xtra logo stands for "electronic extra" and indicates that Figure 7 appears in color online.

doi:10.1094/PHYTO-100-3-0252

(C) 2010 The American Phytopathological Society which was also found in CelA of $C$. michiganensis subsp. sepedonicus (25). A homologue of CelA lacking the third domain (CelB) is present on the chromosome (16). C. michiganensis subsp. michiganensis also produces a variety of cell wall-degrading enzymes (e.g., xylanase, pectate lyases, and polygalacturonase), which might be involved in canker production and tissue maceration (16).

A prominent characteristic of C. michiganensis subsp. michiganensis is the occurrence of numerous extracellular serine proteases belonging to three different families (16). Noteworthy are two homologues of the virulence factor pat-1 located on the pCM2 plasmid, and seven chromosomal homologues (i.e., $\operatorname{chpA-}$ $\operatorname{chp} G$ of which three, $\operatorname{chp} A, B$, and $D$, are pseudogenes) located on a large pathogenicity island (PAI) of $\approx 129 \mathrm{~kb}$ known as the chp/tomA region (16). The chp/tomA PAI appears to be involved in the pathogenicity of $C$. michiganensis subsp. michiganensis: a C. michiganensis subsp. michiganensis mutant lacking the complete PAI region exhibited impaired virulence and was unable effectively to colonize tomato (16). Moreover, $\operatorname{chp} C$ was recently shown to be directly implicated in a virulent interaction with the host (36). Although attempts to demonstrate proteolytic activity of pat-1 with various substrates were unsuccessful, its enzymatic action could be inferred from the elimination of its contribution to virulence by substitution of the serine residue with threonine in its catalytic domain (2). Thus, it is possible that, similarly to CelA, Pat-1 might act directly on a protein located in the host cell wall or membrane, as a substrate-specific protease (2).

During compatible host-pathogen interactions, phytopathogenic bacteria must overcome the immune response of their host plants (23). Two phases of the plant immune system are recog- 
nized: the first, the basal defense phase, uses transmembrane pattern recognition receptors that respond to microbe or pathogen-associated molecular patterns (e.g., MAMPS or PAMPS) such as flagellin or lipopolysaccharide (3); the second phase acts largely inside the cell, using polymorphic resistance genes (7). The basal defense responses do not discriminate between pathogenic and nonpathogenic microbes and include induction of pathogenesis-related (PR) proteins such as chitinases, glucanases, and proteases $(30,31)$. In gram-negative phytopathogenic bacteria both phases of the immune response are effectively suppressed by type III effectors, which are translocated into the host cells via the type III secretion system (T3SS) $(6,9)$. Although $C$. michiganensis subsp. michiganensis lacks a T3SS, it might possess virulence effectors that function through targets on the external plant membrane or that are imported into the cell by as yet unknown mechanisms, as was recently shown for oomycete plant pathogens (38).

The present study was undertaken to investigate the sequential expression of the plasmid-borne genes celA and pat-1 and of additional chromosomal genes encoding serine proteases and cell wall-degrading enzymes during early stages of tomato infection by $C$. michiganensis subsp. michiganensis. Moreover, the relationship between expression of these genes and the presence of the virulence plasmids (pCM1 and $\mathrm{pCM} 2$ ) and the chp/tomA chromosomal PAI was examined. Finally, the possible suppression of tomato PR proteins by products of putative virulence genes was investigated.

\section{MATERIALS AND METHODS}

Bacterial strains and growth conditions. The $C$. michiganensis subsp. michiganensis strains used in the present study were the wild-type pathogenic strain $C$. michiganensis subsp. michiganensis NCPPB382 (Cmm382) and its derivatives, Cmm100 (lacking the two virulence plasmids, pCM1 and pCM2), Cmm101 (lacking pCM2), Cmm102 (lacking pCM1) (27), and Cmm27, a deletion mutant of Cmm382 lacking the $\operatorname{chp} /$ tomA region (generated in this study). The $C$. michiganensis subsp. michiganensis strains were grown at $25^{\circ} \mathrm{C}$ for 48 to $72 \mathrm{~h}$ on nutrient broth or agar (Difco, Le Pont de Claix, France) or M9 medium (MA) agar plates $\left(\mathrm{Na}_{2} \mathrm{HPO}_{4}\right.$ [6 g/liter], $\mathrm{KH}_{2} \mathrm{PO}_{4}$ [3 g/liter], $\mathrm{NH}_{4} \mathrm{Cl}$ [1 g/liter], $\mathrm{NaCl}$ [0.5 g/liter], $\mathrm{MgSO}_{4}[1 \mathrm{mM}], \mathrm{CaCl}_{2}[0.01 \mathrm{mM}]$, methionine [200 mg/liter], thiamine [200 mg/liter], nicotinic acid [20 mg/liter], glucose [2 g/liter], and agar [8 g/liter]) or MA medium supplemented with $0.5 \%$ carboxyl methyl cellulose (CMC). All strains were maintained as glycerol stocks at $-80^{\circ} \mathrm{C}(34)$.

Construction of $\mathbf{C m m 2 7}$. A deletion mutant lacking the chp/tomA region was previously reported (16). However, this mutant lacked pCM2; therefore, a similar mutant containing both plasmids (pCM1 and pCM2) was sought. During construction of a knock-out mutant of $\mathrm{Cmm} 382$ in a peptide $\mathrm{ABC}$ transporter (CMM_1960) by insertion of a chloramphenicol (cmx) resistance gene cassette, a deletion of the chp/tomA region was obtained spontaneously. To confirm the nature of the deletion the following procedures, which were used to analyze chp/tomA deletion (16) were employed. A polymerase chain reaction (PCR) analysis with primers DR1a-F and DR1b-R (Table 1) of the left and right direct repeats flanking the chp/tomA region was conducted. A $2.7-\mathrm{kb}$ amplified fragment from $\mathrm{Cmm} 27$ confirmed that the PAI region was lost. Pulsed-field gel electrophoresis of $C m m 27$ DNA according to Kleitman et al. (24) showed a chromosomal deletion of $140-\mathrm{kb}$ in comparison with Cmm382 (data not shown). Additionally PCR amplification of $p p a A, \operatorname{chpC}$, and tomA, which are located on the PAI region, was conducted according to Kleitman et al. (24) with template DNA of Cmm27 and the wild-type strain. Results indicated that these genes were absent in the mutant strain. In order to confirm the presence of pCM1 and pCM2 in Cmm27 PCR with primers based on the sequences of celA and pat-1 indicated the presence of both plasmids.. The inserted $c m x$ cassette into the peptide $\mathrm{ABC}$ transporter did not affect $C$. michiganensis subsp. michiganensis virulence. A $C$. michiganensis subsp. michiganensis mutant with identical cmx location, as confirmed by Southern hybridization, but with the complete chp/tomA region was subjected to a pathogenicity test on tomato. Wilting symptoms were identical to those of the wild-type strain (data not shown). Furthermore, mutation in the ABC transporter alone did not affect the expression of the genes tested in this study (i.e., celA, pat-1, $\operatorname{chp} C$, and ppaA).

The construction of clones for marker exchange and electroporation into $\mathrm{Cmm} 382$ were carried out according to Stork et al. (36). Chloramphenicol was used at a concentration of $10 \mu \mathrm{g} / \mathrm{ml}$.

Plant inoculation and colonization tests. Seeds of the tomato (Solanum lycopersicum) line Rio Grande (32) were germinated in

TABLE 1. Relevant primers used for quantitative reverse transcription-polymerase chain reaction analysis

\begin{tabular}{|c|c|c|}
\hline $\begin{array}{l}\text { Clavibacter michi- } \\
\text { ganensis subsp. } \\
\text { michiganensis } \\
\text { genes }\end{array}$ & Sequence $\left(5^{\prime} \rightarrow 3^{\prime}\right)$ & $\begin{array}{l}\text { Expressed } \\
\text { gene }\end{array}$ \\
\hline $\begin{array}{l}\text { gyrARTFow } \\
\text { gyrARTRev }\end{array}$ & $\begin{array}{l}\text { GTGGTCGGCGAGGTC } \\
\text { GCGCGAGCGGGTAG }\end{array}$ & gyrA \\
\hline $\begin{array}{l}\text { qcrARTFow } \\
\text { qcrARTRev }\end{array}$ & $\begin{array}{l}\text { CCGACAAGGACCCGAAGAAGG } \\
\text { GATGCCGACGCCGAGGAAC }\end{array}$ & $q c r A$ \\
\hline $\begin{array}{l}\text { bipARTFow } \\
\text { bipARTRev }\end{array}$ & $\begin{array}{l}\text { GCGTTCTGCTTCTTCAGTC } \\
\text { CAACATGCGTCAGTCCAC }\end{array}$ & bipA \\
\hline $\begin{array}{l}\text { celARTFow } \\
\text { celARTRev }\end{array}$ & $\begin{array}{l}\text { GGTTCTCCGCATCAAACTATCC } \\
\text { TGCTTGTCGCTCGTCGTC }\end{array}$ & celA \\
\hline $\begin{array}{l}\text { pat-1RTFow } \\
\text { pat-1RTRev }\end{array}$ & $\begin{array}{l}\text { GCTGATTCGCGAGAGGATC } \\
\text { GTTCTCGGTTGCTGTGTCGC }\end{array}$ & pat -1 \\
\hline $\begin{array}{l}\text { chpCRTFow } \\
\text { chpCRTRev }\end{array}$ & $\begin{array}{l}\text { GACTGCTAATCACTGTGTTG } \\
\text { CAATAAACCGTTCCGATGG }\end{array}$ & $\operatorname{chpC}$ \\
\hline $\begin{array}{l}\text { ppaARTFow } \\
\text { ppaARTRev }\end{array}$ & $\begin{array}{l}\text { AATCGGGCTGGTTCTGGTTT } \\
\text { AGATTCTGCGGCATCTGCAT }\end{array}$ & рраA \\
\hline $\begin{array}{l}\text { celBFow } \\
\text { celBRev }\end{array}$ & $\begin{array}{l}\text { GGAGACCACCAGCGACAAG } \\
\text { TGAACGACCAGAACGACGAG }\end{array}$ & celB \\
\hline $\begin{array}{l}\text { pelA1Fow } \\
\text { pelA1Rev }\end{array}$ & $\begin{array}{l}\text { GTGCGTTCCTGCGGTAAC } \\
\text { GCGGATGGTGATGTGGTC }\end{array}$ & pelA1 \\
\hline $\begin{array}{l}\text { xysAFow } \\
\text { xysARev }\end{array}$ & $\begin{array}{l}\text { ACGGGCAACAGCGAGAAC } \\
\text { GATCATCGTGAACAGGTCCTTG }\end{array}$ & xys $A$ \\
\hline $\begin{array}{l}\text { xysBFow } \\
\text { xysBRev }\end{array}$ & $\begin{array}{l}\text { AAGCCCGAGAGCGTCCAG } \\
\text { TGCGAGTGCCAGAACAGC }\end{array}$ & $x y s B$ \\
\hline $\begin{array}{l}\text { DR1a-F } \\
\text { DR1b-R }\end{array}$ & $\begin{array}{l}\text { GTGCAGCTGCATGGGTC } \\
\text { GAGTTGTTGCTACAGCCATCC }\end{array}$ & $\begin{array}{l}\text { chp/tomA } \\
\text { region }\end{array}$ \\
\hline$\underline{\text { Tomato plant genes }}$ & Sequence $\left(5^{\prime} \rightarrow 3^{\prime}\right)$ & $\begin{array}{l}\text { Accession } \\
\text { no. }\end{array}$ \\
\hline$G A P D H$ & $\begin{array}{l}\text { F: CTGGTGCTGACTTCGTTGTTG } \\
\text { R: GCTCTGGCTTGTATTCATTCTCG }\end{array}$ & U97257 \\
\hline $\begin{array}{l}\text { Polygalacturonase } \\
\text { inhibitor (PG) }\end{array}$ & $\begin{array}{l}\text { F: CCTTTGTGGCTCTCCCTTG } \\
\text { R: TTCATTAGACCCTCGCATACG }\end{array}$ & L26529 \\
\hline$P R-1$ & $\begin{array}{l}\text { F: AACGCTCACAATGCAGCTCGTA } \\
\text { R: AAGGTCCACCAGAGTGTTGCAT }\end{array}$ & EU589238 \\
\hline$P R-5$ & $\begin{array}{l}\text { F: AAACGGTGAATGCCCTGGTTCA } \\
\text { R: AGGACCACATGGACCGTGATTA }\end{array}$ & AJ277064 \\
\hline PR-5 isoform & $\begin{array}{l}\text { F: ATCGAGGCCAAACATGGGTCAT } \\
\text { R: TTGGCATGAACCTCTACCAGCA }\end{array}$ & AY093595 \\
\hline $\begin{array}{l}\text { PR-P69 gene } \\
\text { subtilisin-like } \\
\text { endoprotease }\end{array}$ & $\begin{array}{l}\text { F: ATGTTTGGCAGGTGGTGGAGTT } \\
\text { R: TGGAATCACATGAGCATCGGCT }\end{array}$ & X95270 \\
\hline Chitinase class III & $\begin{array}{l}\text { F: ATGCTTTCTCTTGGTGGTGGTG } \\
\text { R: AATGTTGTGTTGTCCCGCCTTC }\end{array}$ & Z11563 \\
\hline PR1a (P4) & $\begin{array}{l}\text { F: GTGCTGGGGAGGAACCTTGCC } \\
\text { R: AACGAGCCCGACCACAACC }\end{array}$ & AJ011520 \\
\hline Chitinase class II & $\begin{array}{l}\text { F: GCAGGGAGTGCAATAGGTGTGAA } \\
\text { R: TTGGCTGTTGTGCTGTCATCCA }\end{array}$ & U30465 \\
\hline
\end{tabular}


peat-scoria (crushed volcanic stones) for 20 days. The seedlings were then transferred into pots and grown in a growth chamber at $25^{\circ} \mathrm{C}$ with a photoperiod of $16 \mathrm{~h}$. Stems of 4 -week-old tomato seedlings were punctured three times at the junction of the first two leaves, with a needle that had been dipped into a bacterial suspension of $10^{8}$ cells $/ \mathrm{ml}$, or into distilled water for mock inoculation, prior to RNA extraction. Inoculum was prepared from $C$. michiganensis subsp. michiganensis bacteria grown for $48 \mathrm{~h}$ on NA and suspended in distilled water.

Colonization by $C$. michiganensis subsp. michiganensis strains in tomato seedlings was carried out as follows: $100 \mu \mathrm{l}$ of bacterial suspensions of $10^{9}$ and $5 \times 10^{5}$ cells $/ \mathrm{ml}$ was injected into the stem regions of the first two leaves with a 21-gauge syringe. At various time points $(0,1,2,4,7,10$, and 15 days after inoculation), three seedlings per treatment were independently collected and macerated with $3 \mathrm{ml}$ of $10 \mathrm{mM}$ phosphate buffer $(\mathrm{pH} \mathrm{7.0)}$ and serial 10 -fold dilutions were plated on CNS plates according to Hadas et al. (18). The numbers of colony-forming units (CFU) per gram fresh weight were determined, and the average of three independent experiments was calculated.

RNA extraction and cDNA synthesis. For RNA isolation from in vitro-cultured bacteria, wild-type strain $C m m 382$ was grown on agar plates of MA medium or MA supplemented with CMC for $48 \mathrm{~h}$ at $28^{\circ} \mathrm{C}$. The cells were then scraped from plates, washed once, and suspended with sterile water to a final $\mathrm{OD}_{600}$ of 0.5 , which corresponds to a density of approximately $10^{9} \mathrm{CFU} / \mathrm{ml}$. Bacterial suspensions were centrifuged and cells pellets were immediately frozen in liquid $\mathrm{N}_{2}$ and kept at $-80^{\circ} \mathrm{C}$ prior to RNA extraction.

RNA extractions were carried out from in vitro-cultured cells after $48 \mathrm{~h}$ and from cells grown in planta at different time intervals. For each time point two separate pools of three to five inoculated stem junction parts (approximately $2 \mathrm{~cm}$ long) were cut from independent infected or mock-inoculated plants and used for RNA extraction. To improve bacterial cells lysis, $1 \mu \mathrm{lof}$ Ready-Lyse Lysozyme Solution (Epicentre, Biotechnologies, Madison, WI) was added to each sample after resuspension in TE buffer following the manufacturer's instructions. The MasterPure RNA Purification Kit (Epicentre) was used to isolate total RNA according to the manufacturer's instructions. RNA quantification was performed with a NanoDrop 1000 spectrophotometer (Thermo Fisher Scientific, Epsom, Surrey, UK). To remove residual genomic DNA, the isolated RNA was treated with DNase (Turbo DNA-free, Ambion Inc., Austin, TX). The absence of DNA contamination in RNA samples was then validated by quantitative reverse-transcriptase (qRT)-PCR and subsequently used for cDNA synthesis. The quality of DNAse-treated samples was verified by running aliquots of purified RNA on a denaturing agarose gel (ribosomal RNA bands are clearly visible with a ratio of approximately 2:1 from bacterial and plant RNA samples). Reverse transcription was carried out from $1 \mu \mathrm{g}$ of total RNA by using the Verso cDNA Kit (Thermo Scientific, Epsom, UK) with random hexamer primers according to the manufacturer's instructions. Triplicates of cDNA syntheses were performed for $60 \mathrm{~min}$ at $53^{\circ} \mathrm{C}$. cDNA synthesis for studying the expression of plant genes was carried out at $42^{\circ} \mathrm{C}$.

Expression analysis by qRT-PCR. Specific primers for realtime PCR were designed by using the AlleleID program (Premier BioSoft International, Palo Alto, CA) according to the sequence of the corresponding genes (Table 1). The expected size of the amplicons was approximately $85 \mathrm{bp}$. PCR efficiencies for each primer pair were calculated from the slope of standard curves based on the amplification of four out of seven cDNA dilutions (33). Three C. michiganensis subsp. michiganensis genes, gyrA (CMM_0007), bipA (CMM_2179), and qcrA (CMM_1836), were tested for use as suitable reference genes. Real-time PCR was performed for each gene in MA medium culture and in inoculated plants. The $\mathrm{C}_{\mathrm{T}}$ values of these genes was used as raw data for analysis of gene expression stability (M) by using the freely available geNORM software (40). Lowest and similar $\mathrm{M}$ value (most stable) were obtained for the three genes and gyrA and bipA were further used as reference $C$. michiganensis subsp. michiganensis genes.

The GAPDH (glyceraldehyde-3-phosphate dehydrogenase) from tomato were used as internal normalization control based on a previous study described by Balaji et al. (1).

Real-time PCR reactions were performed in triplicate and contained $4 \mu \mathrm{l}$ of the diluted cDNA, $200 \mathrm{nM}$ of each primer, and Power SYBR Green PCR Master Mix (Applied Biosystems, Warrington, UK) in a final volume of $15 \mu \mathrm{l}$. Real-time detection was performed with a Rotor-Gene 3000 (Corbett Research, Sydney, Australia). The cycling program consisted of an initial denaturation of $10 \mathrm{~min}$ at $95^{\circ} \mathrm{C}$, followed by 40 cycles of $5 \mathrm{~s}$ at $95^{\circ} \mathrm{C}, 15 \mathrm{~s}$ at $60^{\circ} \mathrm{C}$, and $20 \mathrm{~s}$ at $72^{\circ} \mathrm{C}$. Fluorescence was measured at the end of each cycle. Three negative controls and a tenfold dilution series of a mixture of all cDNAs were used as template to construct calibration curves designed for each pair of primers. The absence of nonspecific products and primers dimers was confirmed by analysis of melting curves. Relative quantification was calculated on the basis of $\Delta \Delta \mathrm{C}_{\mathrm{T}}$. The $\Delta \mathrm{C}_{\mathrm{T}}$ value was determined by subtracting the $\mathrm{C}_{\mathrm{T}}$ values of the target gene from that of the reference gene and then normalizing as suggested by Rotor-Gene $\left(\Delta \Delta \mathrm{C}_{\mathrm{T}}\right)$. The final relative quantification value is $2^{-\Delta \Delta C}$, which represent the level of expression of the gene in relation to the control (cultured cells after $48 \mathrm{~h}, C$. michiganensis subsp. michiganensis or mock-inoculated plants). Each experiment was conducted three times and statistical analysis was performed with the Excel software (Microsoft, Seattle, WA) and JMP V7 (SAS Institute, Cary, NC).

\section{RESULTS}

The plasmid-borne celA and pat-1 are extensively transcribed by $C$. michiganensis subsp. michiganensis during early stages of tomato infection. Expression levels of celA and pat-1 were measured with the qRT-PCR at various time points following inoculation of tomato with $\mathrm{Cmm} 382$, and were compared with those obtained in culture media. cDNA samples were generated from total RNA extracts as described in Materials and Methods. The transcript level of celA was slightly induced (twofold) in culture grown on M9 medium (MA) supplemented with carboxymethyl cellulose (CMC) compared with the unsupplemented medium (Fig. 1A). In contrast to the in vitro conditions, significant elevation of celA relative expression was observed in planta. Thus, the transcription level of celA increased 8- and 14-fold during the initial 12 and $24 \mathrm{~h}$ postinoculation (hpi), respectively, reached a peak of 23 -fold at $72 \mathrm{hpi}$, and then declined to 16.8- and 10.4-fold at 96 and 168 hpi, respectively (Fig. 1A).

Relative expression of pat-1 was greatly induced in C. michiganensis subsp. michiganensis-infected plants compared with that in MA medium. Transcripts were increased approximately 71 -fold at $12 \mathrm{hpi}$, reached levels of 170- and 160-fold at 24 and $72 \mathrm{hpi}$, respectively, and decreased to 75- and 50-fold after 96 and 168 hpi, respectively (Fig. 1B).

Deletion of chp/tomA region in $C$. michiganensis subsp. michiganensis reduces expressions of celA and pat-1 during tomato infection. The mutant $C m m 27$, which lacks the $\approx 129 \mathrm{~kb}$ chp/tomA PAI and is resistant to chloramphenicol was generated as described in Materials and Methods. The relative transcription levels of celA and pat- 1 in Cmm382 and Cmm27 were compared by means of qRT-PCR. Transcript levels of celA in the mutant Cmm27 were reduced by factors of 3.5, 2.8, and 1.96 at 12, 24, and $96 \mathrm{hpi}$, respectively, compared with those in the wild-type strain Cmm382 (Fig. 2A). A similar reduction was observed for pat-1. Thus, pat-1 expression in Cmm 27 was reduced by factors of 2.5, 1.9, and 1.8 at 12, 24, and 96 hpi, respectively (Fig. 2B). 
Expression of serine proteases located on the chp/tomA PAI is highly affected by the presence of the virulence plasmids pCM1 and pCM2. As illustrated in Figure 2, expression of celA and pat-1 was significantly reduced in the absence of the chp/tomA PAI. Therefore, it was of interest to examine whether this relationship reciprocated, i.e., whether the absence of the virulence plasmids affected transcription of the PAI-encoded genes $\operatorname{chp} C$ and $p p a A$, which represent two different families of serine proteases (16). The importance of the chp/tom $A$ region, and particularly of $\operatorname{ch} p$, for virulence has been previously reported $(16,36)$. Relative expression levels of $\operatorname{chpC}$ and ppaA in planta were measured in Cmm382 and compared with those of Cmm100 that lacked the two plasmids. In contrast to the early and high expression level of pat-1 in Cmm382 (Fig. 1), chpC and ppaA were only marginally expressed in the wild-type strain $C m m 382$ at 12 and 24 hpi (Fig. 3). However, at $96 \mathrm{hpi}$, elevated relative expression of both genes (seven- and tenfold, respectively) was observed in the wild-type strain. In the plasmid-free Cmm 100 , transcription of $\operatorname{chpC}$ could not be detected up to $24 \mathrm{hpi}$, and at 96 hpi only a very low level of expression compared with that in the wild type was observed (Fig. 3A). Also, expression of ppaA in Cmm100 was very low at $12,24 \mathrm{hpi}$, and remained low at $96 \mathrm{hpi}$ (Fig. 3B). The results obtained suggest that $\operatorname{chpC}$ and $p p a A$ were transcribed at later stages of infection and that their expression levels were strongly affected by the presence of the plasmids pCM1 and pCM2.

Because Cmm100 lacks both plasmids, it was of interest to examine which of the plasmids, pCM1 or pCM2, was responsible for the low expression levels of $\operatorname{chpC}$ and $p p a A$. Therefore, the relative expression levels of these genes were measured in Cmm101 (lacking pCM2) and Cmm102 (lacking pCM1). The results (Fig. 4A) demonstrated that the expression of $\operatorname{chpC}$ and
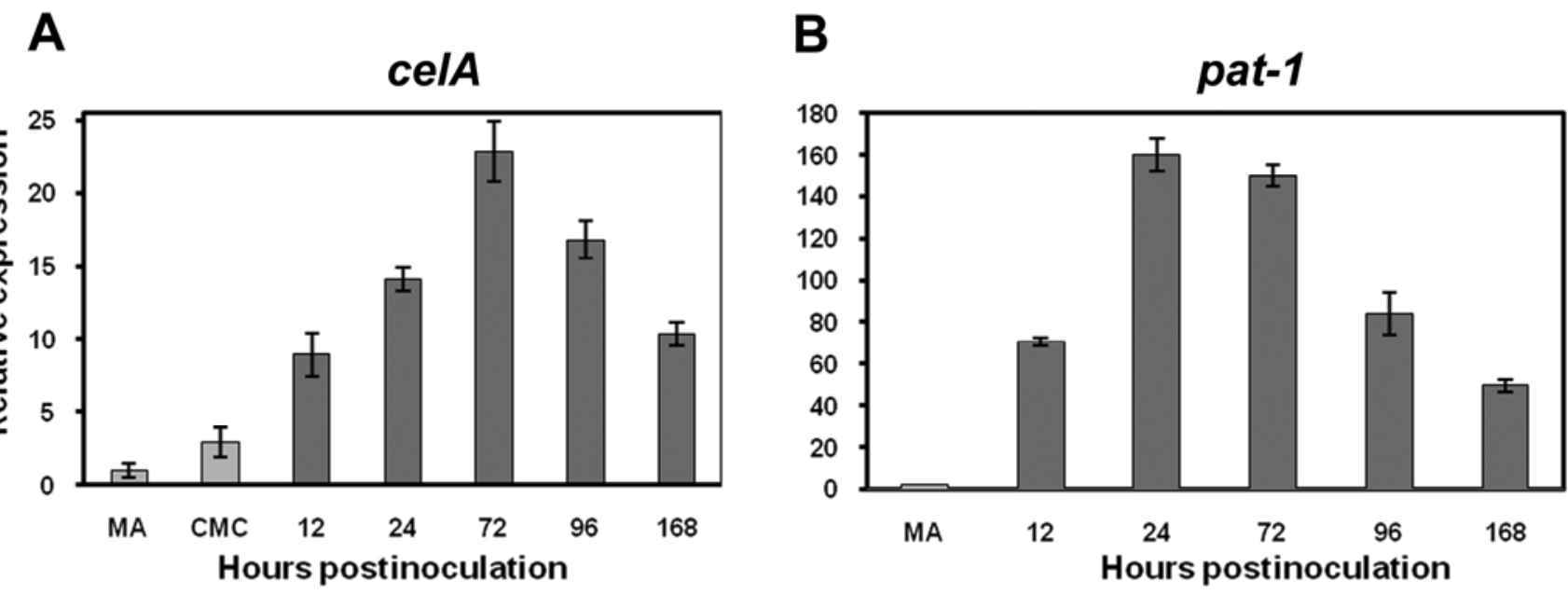

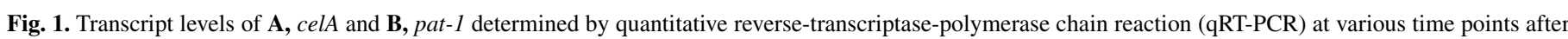

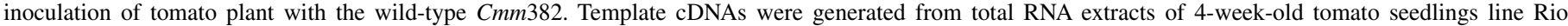

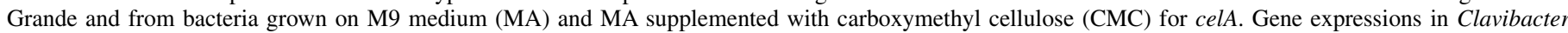

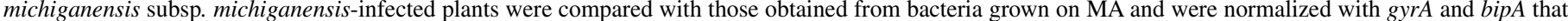

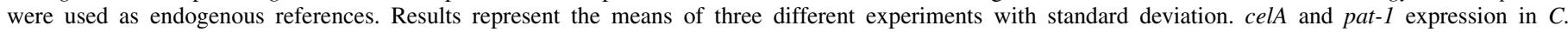
michiganensis subsp. michiganensis-infected plants were statistically different $(P<0.05)$ than in MA according to Student's $t$ test.

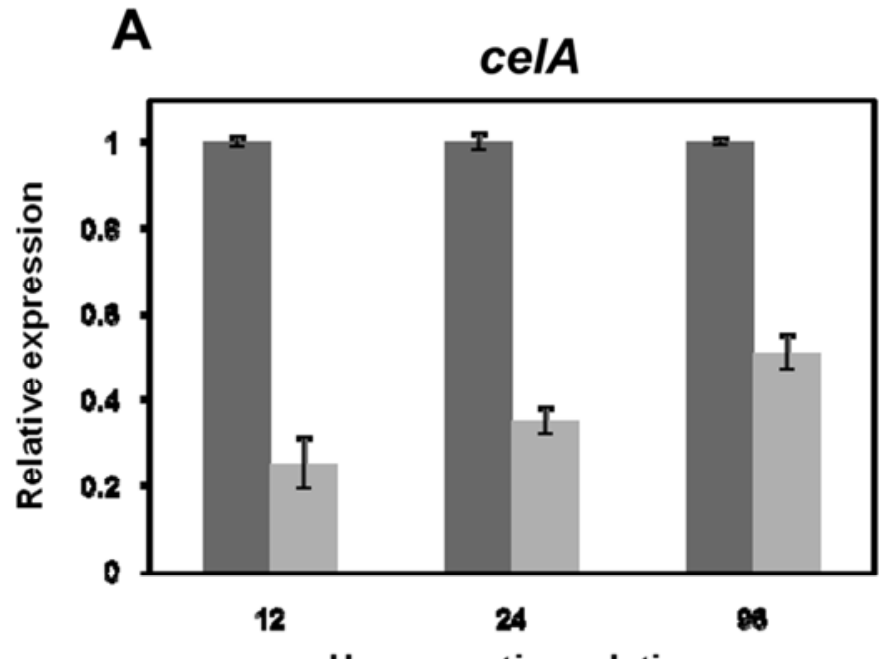

Hours postinoculation

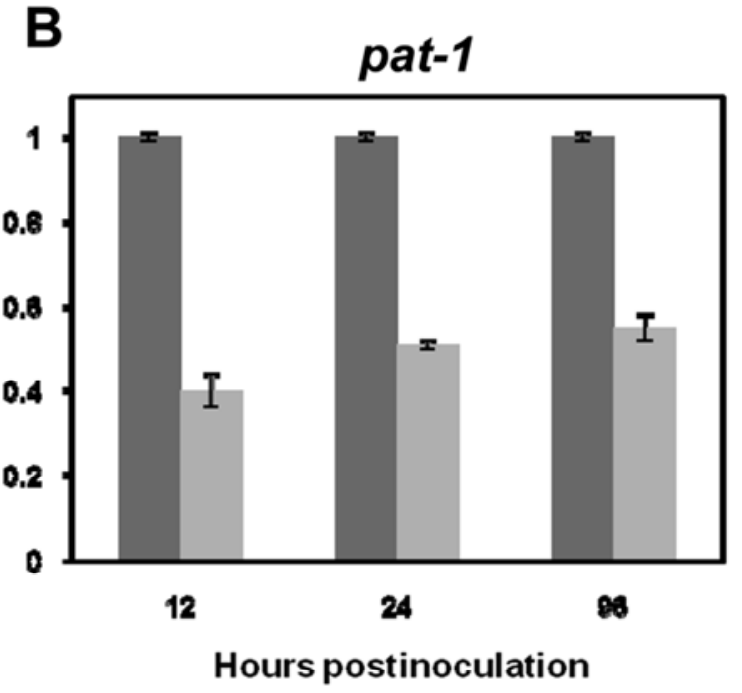

Cmm27

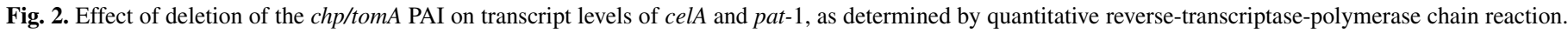

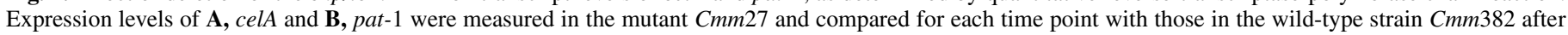

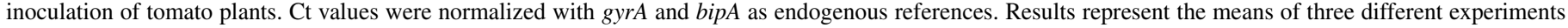

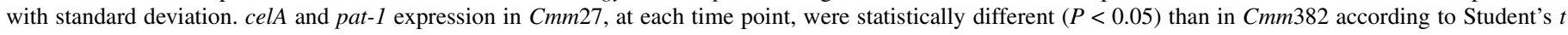
test. 
ppaA at 96 hpi were similar to those obtained for Cmm 100 , indicating that each of the two plasmids had the same effect of reducing the expression levels of the chromosomal serine proteases $\operatorname{ch} \mathrm{C}$ and $p p a A$.

Expression of $C$. michiganensis subsp. michiganensis chromosomal genes encoding cell wall-degrading enzymes during tomato infection. Based on the recently annotated genome of Cmm382 (16), four genes encoding cell-wall degrading enzymes, namely, pelA1 (encoding a pectate lyase), celB (encoding a cellulase), and $x y s A$ and $x y s B$ (encoding xylanases), were chosen for monitoring their transcriptional activity during infection of tomato by $C m m 382, C m m 100$, and $C m m 27$. All these genes (except pelA1) are located on the chromosome outside of the chp/tomA PAI. In Cmm382, transcription of pelA1, which resides on the PAI, was increased fourfold and sevenfold at 12 and $24 \mathrm{hpi}$, respectively, but sharply reduced to almost twice the initial level at 96 hpi (Fig. 5). Relative expression of pelAl in Cmm100 increased more than in Cmm382; it reached sixfold and eightfold induction at 12 and $24 \mathrm{hpi}$, respectively, and then declined sharply by 96 hpi. These results may indicate that pCM1 and pCM2 exerted a slight but significant negative effect on expression of pelA1. A similar effect was observed in the case of celB: substantial increases in its transcription levels were recorded in Cmm100 compared with those in Cmm382, reaching 9.5-fold and 5-fold at 12 and $24 \mathrm{hpi}$, respectively (Fig. 5). After 96 hpi the expression levels of $\mathrm{celB}$ in both $\mathrm{Cmm} 382$ and $\mathrm{Cmm} 100$ were reduced. The transcription level of $\mathrm{celB}$ in $\mathrm{Cmm} 27$, which lacks the chp/tomA region, was similar to $C m m 382$ (Fig. 5). In order to find out which of the two plasmids was responsible for the higher expression levels of $c e l B$ in $C m m 100$ the transcription was measured in Cmm101 and Cmm102 after 12 hpi (Fig. 4B). Results clearly demonstrated that after $12 \mathrm{hpi}$ expression of $\mathrm{celB}$ in strains lacking celA (i.e., Cmm 100 and $C m m 102$ ) was higher by 26- and 14-fold, respectively, than in strains containing celA (i.e., Cmm382 and Cmm101).

Transcription of $x y s A$ and $x y s B$ was also induced following tomato infection with $C m m 382, C m m 100$, and $C m m 27$, but always to a lesser extent than that observed for celB and pelA1 genes (Fig. 5). Relative expression of xysA increased after 96 hpi in $C m m 382$ and $C m m 27$, whereas that of $x y s B$ was higher at 12 and $24 \mathrm{hpi}$, and decreased at $96 \mathrm{hpi}$.

Differential expression of PR proteins in tomato infected by $C m m 382, C m m 27$, and $C m m 100$. It was hypothesized that the expression of host genes associated with defense might be differentially altered in response to tomato infection by virulent and nonvirulent $C$. michiganensis subsp. michiganensis strains. Therefore, relative expressions level of nine genes encoding PR proteins were measured in tomato seedlings inoculated with Cmm382, Cmm27, and Cmm100 compared with mock inoculation. Transcripts levels were measured at $12 \mathrm{hpi}$, using qRT-PCR with specific primers listed in Table 1. Three genes-chitinase class II, polygalacturonase (PG) inhibitor and PR-5 isoform-out of nine that were tested showed different levels of expression during the early stages of infection (Fig. 6). Chitinase II and PG inhibitor showed the highest levels of expression compared with PR-5 isoform. However, the expression levels of chitinase II and PR-5 isoform in Cmm27-inoculated plants were significantly higher than in those inoculated with the wild-type strain or Cmm100, which suggests that genes residing on the PAI might be responsible for suppression of some PR proteins.

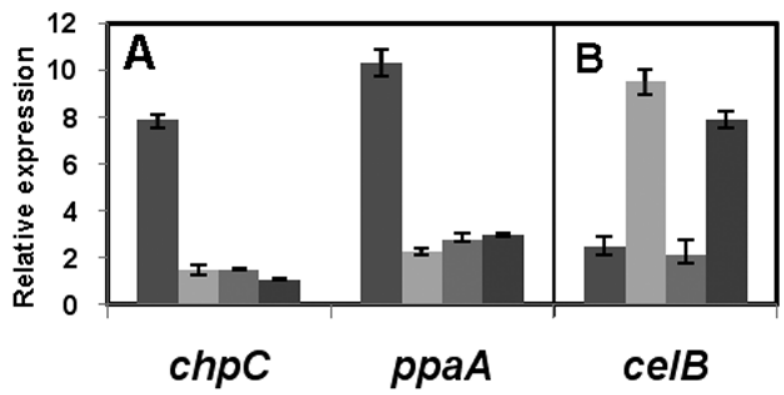

$\because \mathrm{Cmm} 382=\mathrm{Cmm100}=\mathrm{Cmm} 101=\mathrm{Cmm102}$

Fig. 4. Relative expression of chromosomal genes $\operatorname{chpC}$, ppaA, and $c e l B$ during infection of tomato plants with Cmm382, Cmm 100, Cmm101, and Cmm102. Total RNAs were extracted from infected plants collected at $\mathbf{A}, 96 \mathrm{~h}$ and $\mathbf{B}, 12 \mathrm{~h}$ after inoculation, and were used to analyze gene expression by quantitative reverse-transcriptase-polymerase chain reaction. Relative expressions were obtained by comparing the transcript levels in Clavibacter michiganensis subsp. michiganensis-infected plants with those in MA medium and were normalized with gyrA and bipA. Results represent the means of three different experiments with standard deviation. $\operatorname{chp} C$ and $p p a A$ expression in Cmm100, Cmm101, and Cmm102 were statistically different $(P<0.05)$ than in $\mathrm{Cmm} 382$. celB expression in $\mathrm{Cmm} 382$ and $\mathrm{Cmm} 101$ were statistically different than in Cmm100 and Cmm102 according to Student's $t$ test.

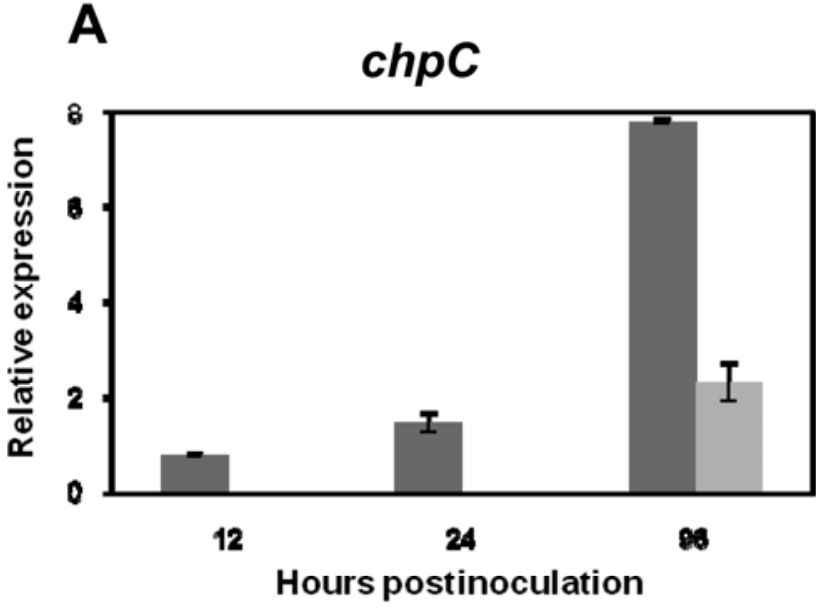

Crmm382
B

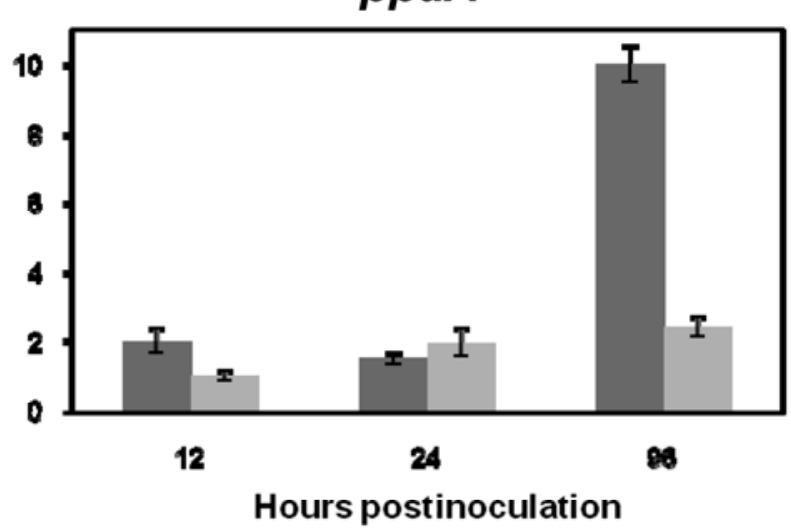

Cmm100

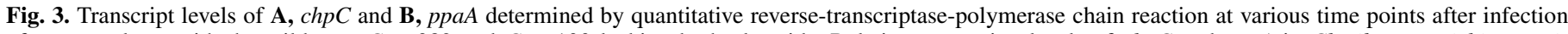

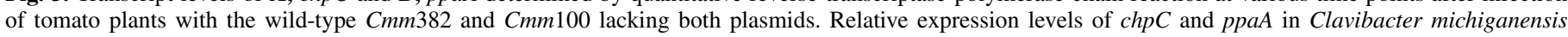

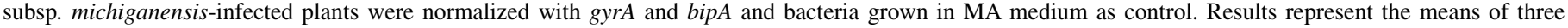

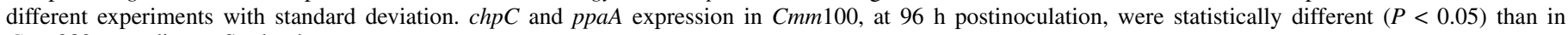
Cmm382 according to Student's $t$ test. 
Colonization of tomato plants by $\mathrm{Cmm382}, \mathrm{Cmm100}$, and Cmm27. Tomato colonization by the nonvirulent strains $\mathrm{Cmm} 100$ and $\mathrm{Cmm} 27$ was compared with that by the virulent wild-type strain Cmm382. Tomato seedlings were inoculated by injecting the $C$. michiganensis subsp. michiganensis suspension into the stems of the first three leaves, and the bacterial population was monitored after 1, 2, 4, 7, 10, and 15 days. Inoculations were with high $\left(10^{9}\right.$ cells $\left./ \mathrm{ml}\right)$ and low $\left(5 \times 10^{5}\right.$ cells $\left./ \mathrm{ml}\right)$ bacterial suspensions. With high inoculum, the multiplication of Cmm382 and Cmm100 were similar and increased by approximately 3.8 orders of magnitude during the first 7 days (Fig. 7A). Initial disease symptoms appeared after 10 days in plants inoculated with the wild-type strain. Fifteen days after inoculation the population of $C m m 382$ was slightly lower than that of Cmm100, probably because of the death of cells as disease symptoms advanced. In contrast, the population of $\mathrm{Cmm} 27$ was significantly lower than that of the wild type during the entire experiment (Fig. 7A). At lower inoculum, the titer of $\mathrm{Cmm} 382$ was slightly higher than that of $C m m 100$ during the initial 7 days after inoculation, but reached the same population level after 10 days (Fig. 7A). Disease symp- toms appeared after 12 days on plants inoculated with $\mathrm{Cmm} 382$. The population of $\mathrm{Cmm} 27$ was 2 to 3 orders of magnitude smaller than those of $C m m 382$ and $C m m 100$ during the entire experimental period. Figure 7B shows plants infected with high concentrations of Cmm382, Cmm100, and Cmm27 3 weeks after inoculation. Disease symptoms were elicited only by $\mathrm{Cmm} 382$. The same results were obtained when the inoculum level was $5 \times 10^{5}$ cells/ml (data not shown).

\section{DISCUSSION}

In this study we have followed transcriptional changes in planta of genes encoding confirmed and putative $C$. michiganensis subsp. michiganensis virulence factors during the initial infection period as well as the transcription of selected tomato genes that might be associated with defense. A notable finding was the early relative expression of the plasmid-borne genes celA of pCM1 and pat-1 of pCM2, which were proven essential for C. michiganensis subsp. michiganensis virulence $(10,22)$. These genes were relatively highly expressed within the first $12 \mathrm{hpi}$, reaching peaks at
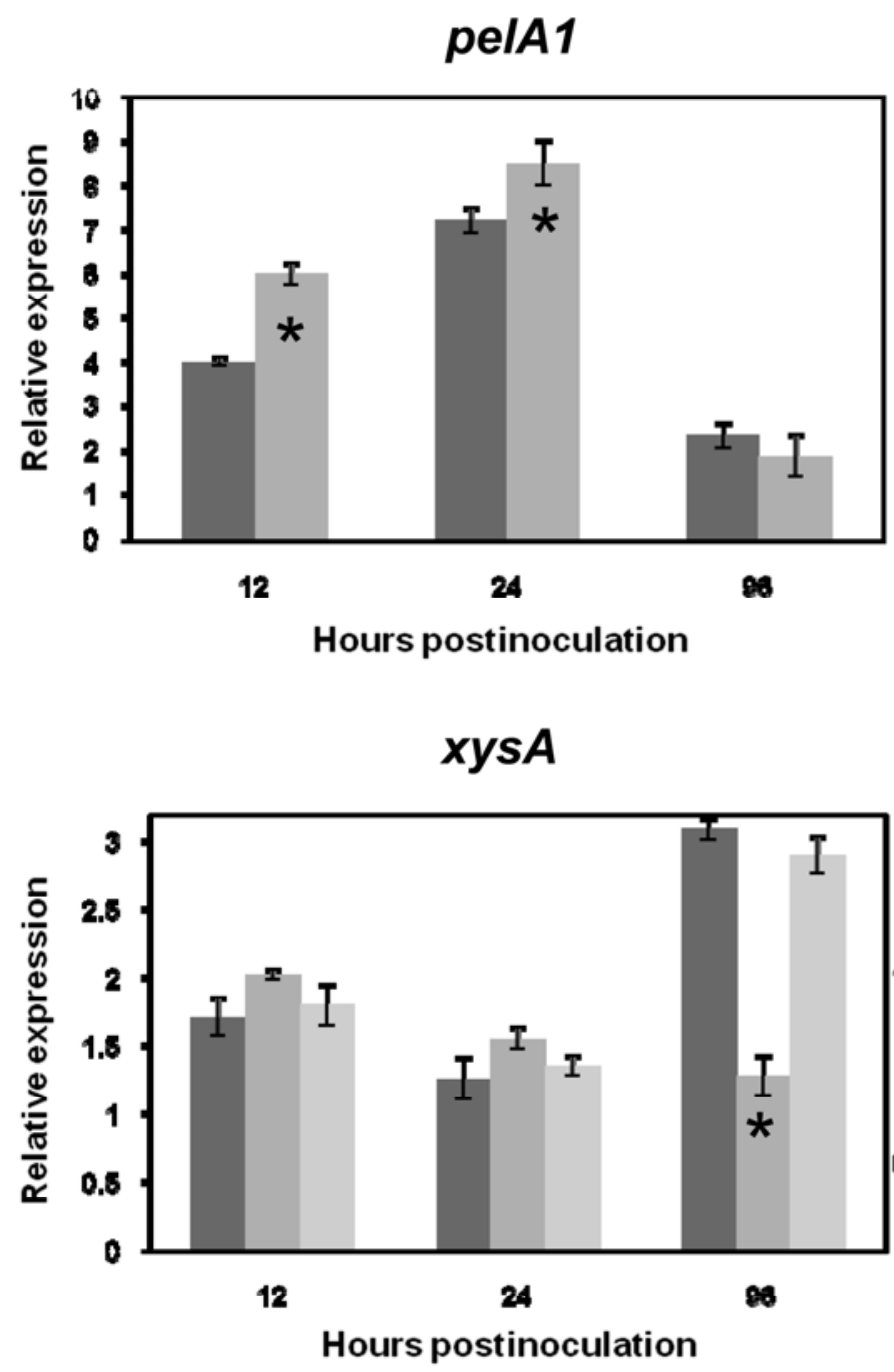

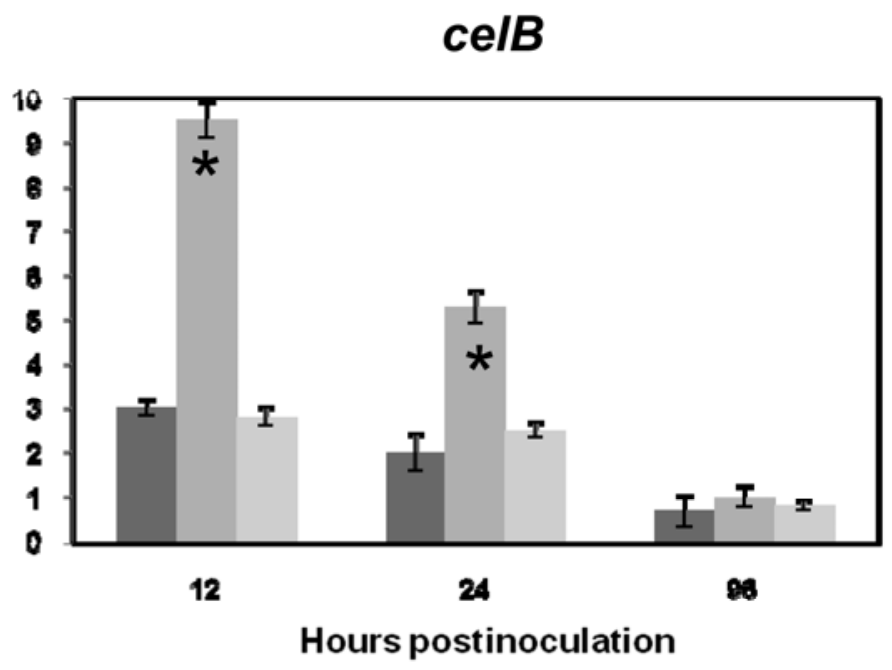

$x y s B$

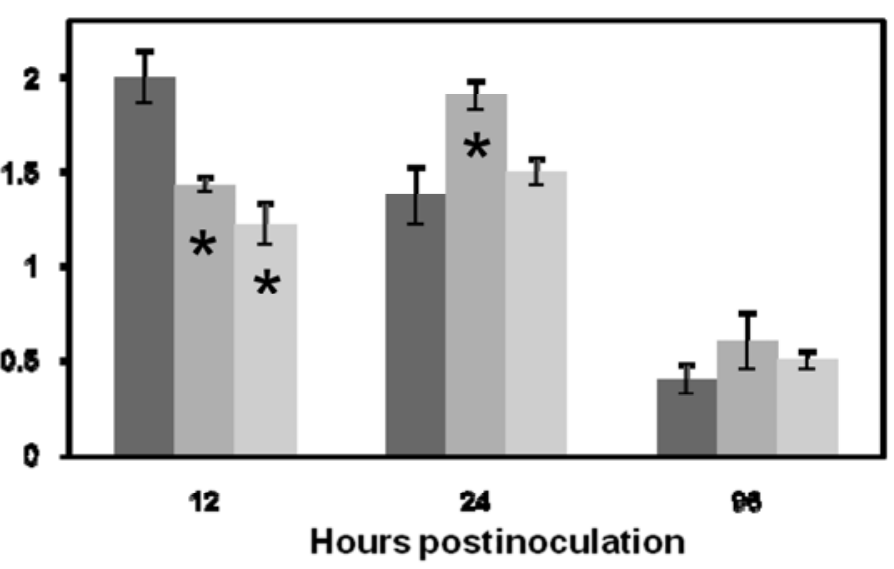

\section{Cmm382 Cmm100 $\square \mathrm{Cmm27}$}

Fig. 5. Transcript levels of pelA1, celB, xysA, and $x y s B$ during infection of tomato with the wild-type Cmm 382 , Cmm 100 , and $C m m 27$. Gene expressions were determined in Clavibacter michiganensis subsp. michiganensis-infected plants by quantitative reverse-transcriptase-polymerase chain reaction compared with those obtained in MA medium and were normalized with $g y r A$ and bipA. Experiments were repeated three times with three replicates for each strain. Errors bars represent the standard deviations and asterisks denote significant differences $(P<0.05)$ in relative expression of the mutants compared to $C m m 382$ at each time point, according to Student's $t$ test. 
72 and 24 hpi for celA and pat-1, respectively, after which they declined steadily but, nevertheless, maintained significant expression levels at least up to 168 hpi (Fig. 1A and B). The transcription of pat-1 and celA in planta was extensively induced in comparison with that in minimal medium, which suggests that host signals are involved in their full activation $(13,31)$. Pat- 1 and CelA are known to affect wilting symptoms but not the colonization of C. michiganensis subsp. michiganensis (12) (Fig. 7), which suggests that they might be associated with mechanisms that trigger the appearance of symptoms. The observation that curing of either pCM1 or pCM2 only reduced virulence whereas loss of both plasmids resulted in a nonpathogenic strain (12) suggests that they act through independent mechanisms.

The current view of molecular plant-pathogen interactions is that pathogens secrete effectors into the apoplast and/or cytoplasm of host plants to suppress host defenses, facilitate colonization and trigger symptoms production $(3,23)$. Effectors may include pathogen enzymes whose plant products act as elicitors which affect virulence (20). The early relative expression of celA in the present study supports the hypothesis that it might be involved in release of elicitors from tomato cell walls. The presence in CelA of the $\alpha$-expansin domain (22), which is assumed to facilitate binding to native cell walls, strengthens this hypothesis. It has long been established that some oligosaccharides, designated as oligosaccharins (15), can induce signal transduction pathways, thereby initiating a variety of plant responses, including growth, development and defense (4). It was also previously demonstrated that short-chain oligogalacturonides may elicit rapid changes in membrane permeability (19) as well as ethylene production $(5,35)$. Disruption of membrane permeability is an important cause of wilting symptoms (39). Moreover, we have previously reported that $C$. michiganensis subsp. michiganensis inoculations of tomato never ripe mutant impaired in ethylene perception, or of transgenic tomato plants with reduced ethylene synthesis, showed significant delay in appearance of wilting symptoms compared with wild-type plants (1). Thus, symptom development may be partially attributed to oligosaccharins generated by CelA that impair membrane permeability and conceivably lead to the production of ethylene. The possibility that some other cell wall-degrading enzymes of $C$. michiganensis subsp. michiganensis such as pelA1, celB, xysA, or xysB participate in the processing that lead to the production of oligosaccharins cannot be excluded, because they, too, are significantly

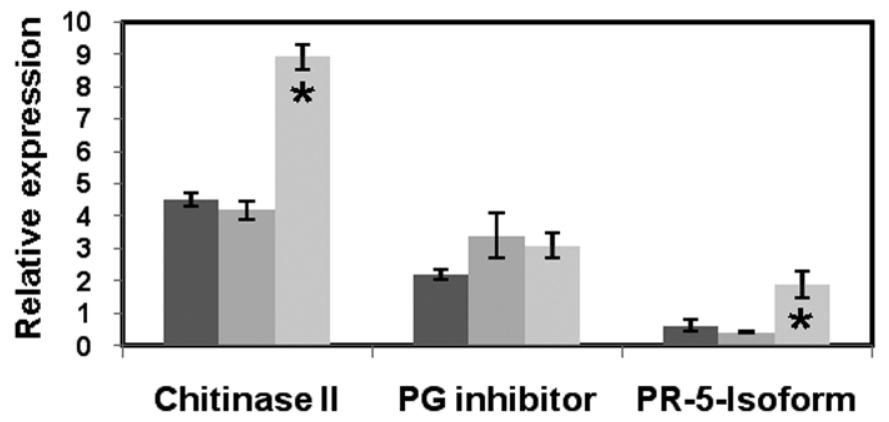

\section{- Cmm382 $\quad \mathrm{Cmm100} \quad \mathrm{Cmm27}$}

Fig. 6. Expression of PR proteins in response to tomato infection by Cmm382, $\mathrm{Cmm} 100$, and $\mathrm{Cmm} 27$, as measured by quantitative reverse-transcriptasepolymerase chain reaction. The transcript levels of Chitinase class II, PGinhibitor and PR-5 isoform were examined in Clavibacter michiganensis subsp. michiganensis-infected plants $12 \mathrm{~h}$ after inoculation. Relative levels of the monitored genes were normalized with $G A P D H$ used as an internal reference and mock-inoculated plants as control. Results represent the means of three different experiments with standard deviation. Asterisks denote significant differences $(P<0.05)$ in gene expression in $C m m 27$ compared with Cmm382 according to Student's $t$ test. expressed during the early incubation period of the disease (Fig. 5). However, they appear not to be involved in the production of primary elicitors because they do not trigger wilting symptoms in Cmm100 lacking CelA and Pat-1. It is noteworthy to mention that the plasmid-borne CelA of $C$. michiganensis subsp. sepedonicus, the causal agent of wilt and ring rot of potato, which is structurally and functionally highly similar to CelA of $C$. michiganensis subsp. michiganensis, is also upregulated during early stages of infection, as some of the Pat-1 homologues of C. michiganensis subsp. sepedonicus (21).

The high induction of pat-1 expression in planta (Fig. 1B) could support the hypothesis that a peptide generated by Pat-1 from a specific plant protein could be formed. Signaling peptides are known to play major roles in animals or yeasts, and a growing number of signal peptides are being isolated and characterized in plants (14). In recent years some type III effectors of gramnegative phytopathogenic Xanthomonas campestris and Pseudomonas syringae, including XopD, AvrPphB, and AvrRpt2, were characterized as cysteine proteases, and their proteolysis of specific host substrates was shown to be an important strategy used by the pathogen to alter host physiology (28). However, serine proteases have not yet been demonstrated to enter and function within the plant cell, therefore, their mode of action might be different. It was recently reported that the serine protease chp-7 was involved in C. michiganensis subsp. sepedonicus virulence on potato (29).

In contrast to the early transcription of the plasmid-borne Pat-1, the relative expression levels of the serine protease genes $\operatorname{ch} p C$ and ppaA, which are located on the chp/tomA PAI (16), increased significantly only after 96 hpi (Fig. 3). The titer of the $\operatorname{chpC}$ mutant in planta has been shown to be drastically reduced, from $9.9 \times 10^{9}$ to $2 \times 10^{7} \mathrm{CFU} / \mathrm{g}$ after 28 days, and the reduced population was correlated with very weak disease symptoms (36). Additionally, it was demonstrated that a bacterial population greater than $10^{8}$ bacteria/g in plant homogenate was necessary for the development of disease symptoms (36) (Fig. 7A). However, reaching a population of $10^{7} \mathrm{CFU} / \mathrm{g}$, as in the case of $\mathrm{Cmm} 27$ (Fig. 7A) might also require an external supply of nutrients from the plant by an as yet unknown mechanism. In this connection it should be stressed that $C$. michiganensis subsp. michiganensis, as well as the other phytopathogenic subspecies or nonpathogenic $C$. michiganensis strains are known to survive as endophytes in plants other than the hosts on which they are pathogenic (12). These findings may suggest that the role of ChpC and possibly also of other serine proteases located on the PAI is to provide the increment in the $C$. michiganensis subsp. michiganensis population that is necessary for converting the endophyte into a pathogen The late increase in expression of $\operatorname{chpC}$ might be in accordance to the latter function.

A most interesting outcome of the present study was the demonstration of interdependence between chromosomal and plasmid-located genes in achieving optimal expression. Thus, the transcription of the plasmid-borne genes celA and pat-1 was reduced by 50 to $80 \%$ in $C m m 27$ lacking the chromosomal chp/tomA region (Fig. 2), whereas relative expression levels of the serine protease homologues $\operatorname{chpC}$ and $p p a A$ were reduced by 70 to $80 \%$ in $C m m 100$ lacking pCM1 and pCM2 (Fig. 3). Previous studies (reviewed in 12) suggested that the evolution of pathogenicity in $C$. michiganensis subsp. michiganensis was achieved by the acquisition of pCM1 and pCM2 via horizontal gene transfer into endophytic $C$. michiganensis subsp. michiganensis strains. These two plasmids are conjugative and could be readily transferred into endophytic $C$. michiganensis subsp. michiganensis strains, thereby rendering them pathogenic. Similarly, pathogenic strains might be cured of these plasmids and thereby become endophytic. Thus, loss and gain of these virulence plasmids appears to be an ongoing process in $C$. michiganensis subsp. michiganensis-infected tomato. In addition to the plasmids, the chromosomal 
PAI, chp/tomA region, which is crucial for increased colonization and virulence on tomato, might also have been acquired by $C$. michiganensis subsp. michiganensis via horizontal gene transfer (16). The mechanisms involved in the cross-talk between the virulence plasmids and the chp/tomA PAI in planta are not yet clear. It might be speculated that common regulatory mechanisms are involved in this phenomenon, as exemplified in the interdependence between celA and celB. Thus, the absence of pCM1 harboring the celA could explain the significant increase (threefold) in relative expression of the chromosomal celB (Figs. 4B and 5). In addition, the presence of the two plasmids elevated the relative expression of the PAI's serine proteases, $\operatorname{chpC}$ and ppaA. Thus, both plasmids were necessary for full expression of $\operatorname{ch} p$ and ppaA (Fig. 4A). This could be attributed to the presence of serine proteases on both plasmids (pat-1 on pCM2 and ppaJ on pCM1) (16). Nevertheless, the possibility that other genes residing on the plasmids might affect the relative expression of cellulases and serine proteases cannot be excluded.

The PR proteins are a group of plant-encoded proteins induced by various stress stimuli (11). They are believed to play an important role in plant defense, in pathogenic constraints, and in general adaptation to stressful environments. Additionally, some PR proteins such as chitinases or glucanases, exhibit enzymatic activity that might be involved in degradation of pathogen cell walls. However, in spite of numerous investigations into the induction of PR proteins, their precise function in plant defenses remained mostly elusive (11). An acceptable paradigm is that pathogens have to suppress/evade the plant basal defenses, which are also represented by the PR proteins, during early stages of infection, to enable in planta growth of the pathogen and subsequent disease induction (23). The possibility that the chp/tomA PAI could be involved in suppression of the basal defense in tomato is inferred from the results presented in Figure 6. Thus, deletion of the PAI in $\mathrm{Cmm} 27$ significantly increased the relative expression of chitinase II and PR-5 isoform during the initial 12 hpi compared with that in strains harboring the PAI ( Cmm382 and Cmm100). Although the expression of PG inhibitor was significantly induced by $\mathrm{Cmm} 27$ compared with that in the wild type, its induction by $\mathrm{Cmm} 100$ was similar to that by $\mathrm{Cmm} 27$. This may suggest that the induction of PG inhibitor might be

A

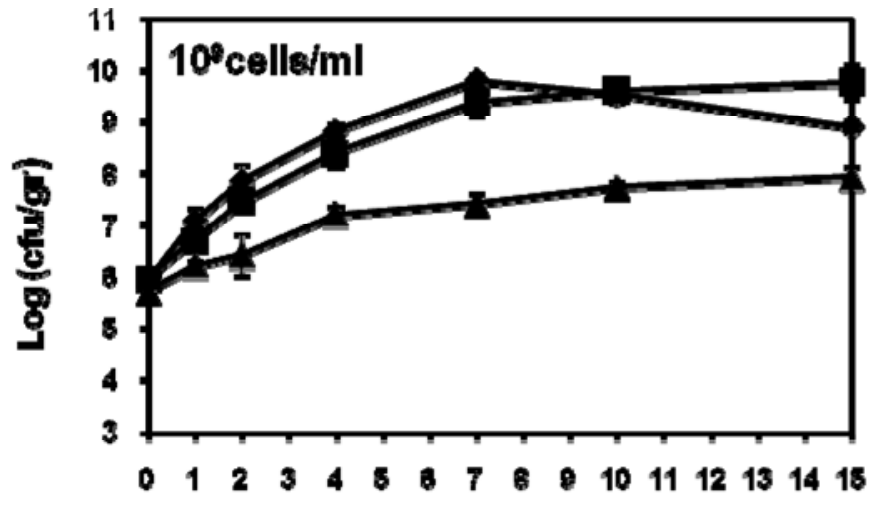

Days after Inoculatlon

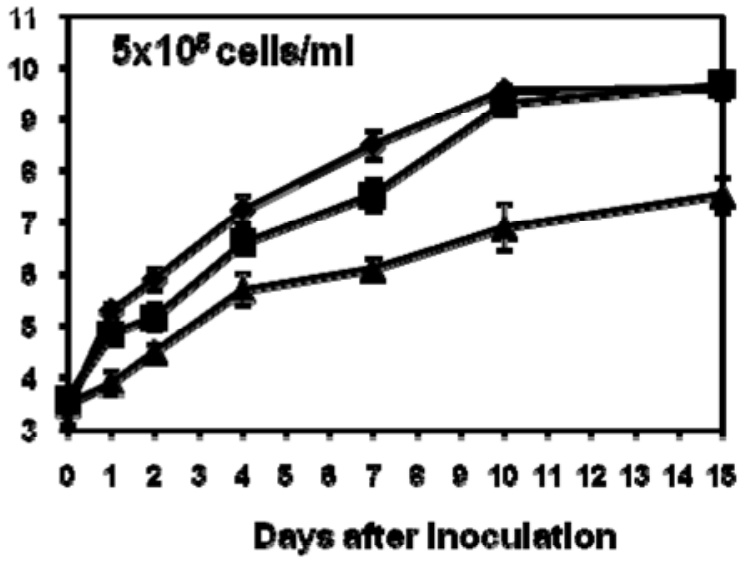

Days after Inoculation

\section{$\rightarrow C m m 382 \rightarrow-C m m 100+C m m 27$}

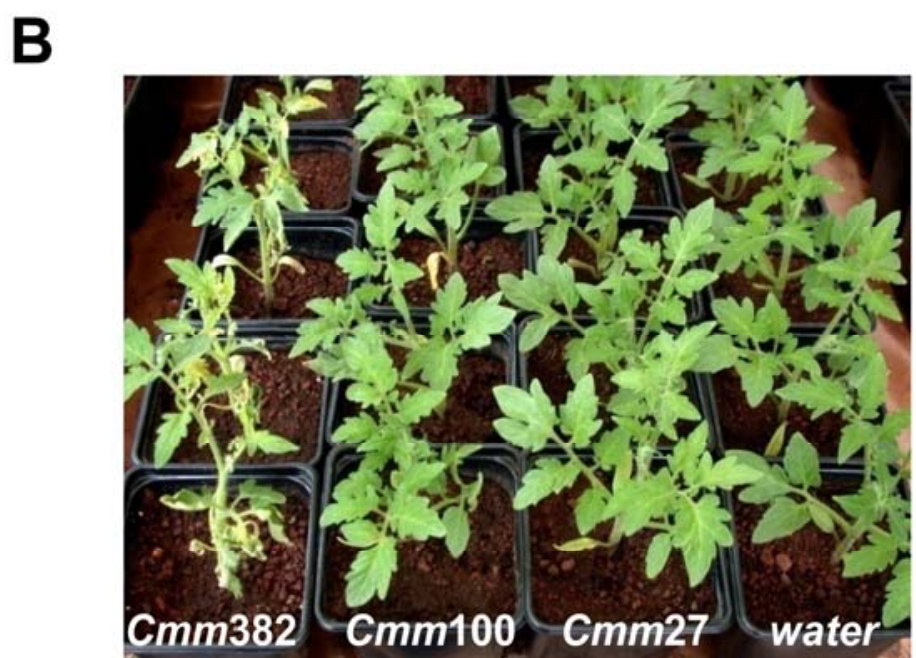

Fig. 7. A, Colonization and B, symptoms development produced by Cmm382, Cmm100, and Cmm 27 in infected tomato plants. A, Stems of 4 -week-old tomato seedlings (line Rio Grande) were inoculated with bacterial suspensions of $10^{9}$ and $5 \times 10^{5} \mathrm{cells} / \mathrm{ml}$, and populations of $\mathrm{Cmm} 382$, Cmm 100 , and $\mathrm{Cmm} 27$ were measured as described in Materials and Methods. Results presented are averages of three independent experiments, with five replicates for each time point. Bars indicate standard deviations. B, Tomato plants infected with Clavibacter michiganensis subsp. michiganensis strains 3 weeks after inoculation with bacterial suspension of $10^{9}$ cells $/ \mathrm{ml}$. 
associated with the presence of the virulence plasmids. It is noteworthy that a microarray study of tomato genes that were upregulated 4 days postinfection by $C$. michiganensis subsp. michiganensis revealed that $21 \%$ could be associated with defense responses (1). In the present study only two out of nine tested tomato genes encoding defense proteins were expressed after 12 hpi (Fig. 6). This observation could imply that additional defense proteins are induced during the early stages of infection.

The results of the present study strengthen the hypothesis that pathogenicity of $C$. michiganensis subsp. michiganensis was acquired by horizontal gene transfer of plasmids, on the one hand, and of chromosomal PAI, on the other hand. A unique mutual interaction between these two elements was demonstrated, which might be involved in the adaptation of endophytic C. michiganensis to pathogenicity on tomato. The fact that additional genes are also induced during early stages of infection might indicate that these chromosomal genes also participate in the virulence process.

\section{ACKNOWLEDGMENTS}

This work was supported by the DGF program for Trilateral Cooperation among Israel, the Palestinian Authority and Germany (Grant No. EI 535/12-2), and the United States-Israel Binational Agricultural Research and Development Fund (BARD) (Grant No. IS-4047-07). Contribution No. 515/09 from the ARO, The Volcani Center, Bet Dagan 50250, Israel.

\section{LITERATURE CITED}

1. Balaji, V., Mayrose, M., Sherf, O., Jacob-Hirsh, J., Eichenlaub, R., Iraki, N., Manulis-Sasson, S., Rechavi, G., Barash, I., and Sessa, G. 2008. Tomato transcriptional changes in response to Clavibacter michiganensis subsp. michiganensis reveal a role for ethylene in disease development. Plant Physiol.146:1797-1809.

2. Burger, A., Gräfen, I., Engemann, J., Niermann, E., Pieper, M., Kirchner, O., Gartemann, K.-H., and Eichenlaub, R. 2005. Identification of homologues to the pathogenicity factor Pat-1, a putative serine protease of Clavibacter michiganensis subsp. michiganensis. Microbiol. Res. 160:417-427.

3. Chisholm, S. T., Coaker, G. L., Day, B., and Staskawicz, B. J. 2006. Hostmicrobe interactions: Shaping the evolution of the plant immune response. Cell 124:803-814.

4. Cote, F., and Hahn, M. G. 1994. Oligosaccharins: Structures and signal transduction. Plant Mol. Biol. 26:1379-1411.

5. Creelman, R. A., and Mullet, J. E. 1997. Oligosaccharins, brassinolides and jasmonates: Nontraditional regulators of plant growth, development and gene expression. Plant Cell 9:1211-1223.

6. da Cunha, L., Seerekha, M.-V., and Mackey, D. 2007. Defense suppression by virulence effectors of bacterial phytopathogens. Curr. Opin. Plant Biol. 10:349-357.

7. Dangl, J. L., and Jones, J. D. G. 2001. Plant pathogens and integrated defense response to infection. Nature 411:826-833.

8. Davis, M. J., Gillaspie, A. G., Vivader, A. K., and Harris, R. 1984. A new genus containing some phytopathogenic coryneform bacteria, including Clavibacter xyli subsp. xyli sp. nov., and Clavibacter xyli subsp. cynodontis subsp. nov., pathogens that cause ratoon stunting of sugar cane and Bermuda grass stunting disease. Int. J. Syst. Bacteriol. 34:107-117.

9. Desveaux, D., Singer, A. U., and Dangl, J. L. 2006. Type III effector proteins: Doppelgangers of bacterial virulence. Curr. Opin. Plant Biol. 9:376-382.

10. Dreier, J. D., Meletzus, D., and Eichenlaub, R. 1997. Characterization of the plasmid encoded virulence region pat-1 of the phytopathogenic Clavibacter michiganensis subsp. michiganensis. Mol. Plant-Microbe Interact. 10:195-206.

11. Edreva, A. 2005. Pathogenesis-related proteins: Research progress in the last 15 years. Gen. Appl. Plant Physiol. 31:105-124.

12. Eichenlaub, R., Gartemann, K.-H., and Burger, A. 2006. Clavibacter michiganensis, a group of Gram-positive phytopathogenic bacteria. Pages 385-422 in: Plant-Associated Bacteria. S. S. Gnanamanickam, ed. Springer, Dordrecht, The Netherlands.

13. Esquerre-Tugaye, M.-T., Boudart, G., and Dumas, B. 2000. Cell wall degrading enzymes, inhibitory proteins and oligosaccharides participate in the molecular dialogue between plants and pathogens. Plant Physiol. Biochem. 38:157-163.
14. Franssen, H. J., and Bisseling, T. 2002. Peptide signaling in plants. PNAS 98:12855-12856.

15. Fry, S. C., Aldington, S., Hetherington, P. R., and Aitken, J. 1993. Oligosaccharides as signals and substrates in plant cell wall. Plant Physiol. 103:1-5.

16. Gartemann, K.-H., Abt, B., Bekel, T., Burger, A., Engemann, J., Flügel, M., Gaigalat, L., and Goesmann, A., 2008. The genome sequence of the tomato-pathogenic actinomycete Clavibacter michiganensis subsp. michiganensis NCPPB382 reveals a large island involved in pathogenicity. J. Bacteriol. 190:2138-2149.

17. Gartemann, K.-H., Kirchner, O., Engemann, J., Gräfen, I., Eichenlaub, R., and Burger, A. 2003. Clavibacter michiganensis subsp. michiganensis: First steps in understanding of virulence of a gram-positive phytopathogenic bacterium. J. Biotechnol. 106:179-191.

18. Hadas, R., Kritzman, G., Kleitman, F., Gefen, T., and Manulis, S. 2005. Comparison of extraction procedures and determination of the detection threshold for Clavibacter michiganensis subsp. michiganensis in tomato seeds. Plant Pathol. 54:643-649.

19. Hahn, M., Bucheli, P., Cervone, F., Doares, S., O’Neill, R., Darville, A., and Albersheim, P. 1989. Roles of cell wall constituents in plant-pathogen interactions. Pages 131-181 in: Plant-Microbe Interactions: Molecular and Genetic Perspectives. T. Kosuge and E. Nester, eds. McGraw-Hill, New York.

20. Hogenhout, S. A., Van der Hoorn, R., Terauchi, R., and Kamoun, S. 2009. Emerging concepts in effector biology of plant-associated organisms. Mol. Plant-Microbe Interact. 22:115-122.

21. Holtsmark, I., Takle, G. W., and Bruberg, M. B. 2008. Expression of putative virulence factors in the potato pathogen Clavibacter michiganensis subsp. sepedonicus during infection. Arch. Microbiol. 189:131139.

22. Jahr, H., Dreier, J., Meletzus, D., Bahro, R., and Eichenlaub, R. 2000. The endo-beta-1,4-glucanase CelA of Clavibacter michiganensis subsp. michiganensis is a pathogenicity determinant required for induction of bacterial wilt of tomato. Mol. Plant-Microbe Interact. 13:703-714.

23. Jones, J. D. G., and Dangl, J. L. 2006. The plant immune system. Nature 444:323-329.

24. Kleitman, F., Barash, I., Burger, A., Iraki, N., Falah, F., Sessa, G., Weinthal, D., Chalupowicz, L., Gartemann, K.-H., Eichenlaub, R., and Manulis-Sasson, S. 2008. Characterization of Clavibacter michiganensis subsp. michiganensis population in Israel. Eur. J. Plant Pathol. 121:463475.

25. Laine, M. J., Haapalainen, M., Wahlroos, T., Kankare, K., Nissinen, R., Kassuwi, S., and Metzler, M. C. 2000. The cellulose encoded by the native plasmid of Clavibacter michiganensis ssp. sepedonicus plays a role in virulence and contains an expansin-like domain. Physiol. Mol. Plant Pathol. 57:221-233.

26. Meletzus, D., Bermpohl, A., Dreier, J., and Eichenlaub, R. 1993. Evidence for plasmid-encoded virulence factors in the phytopathogenic bacterium Clavibacter michiganensis subsp. michiganensis NCPPB382. J. Bacteriol. 175:2131-2136.

27. Meletzus, D., and Eichenlaub, R. 1991. Transformation of the phytopathogenic bacterium Clavibacter michiganensis subsp. michiganensis by electroporation and development of a cloning vector. J. Bacteriol. 173:184-190.

28. Mudgett, M. 2005. New insights to the function of phytopathogenic bacterial Type III effectors in plants. Annu. Rev. Plant Biol. 56:509-531.

29. Nissinen, R., Xia, Y., Mattinen, L., Ishimaru, C. A., Knudson, D. L., Knudson, S. E., Metzler, M., and Pirhonen, M. 2009. The putative secreted serine protease chp-7 is required for full virulence and induction of a nonhost hypersensitive response by Clavibacter michiganensis subsp. sepedonicus. Mol. Plant-Microbe Interact. 22:809-819.

30. Nomura, K., Melotto, M., and He, S.-Y. 2005. Suppression of host defense in compatible plant-Pseudomonas syringae interactions. Curr. Opin. Plant Biol. 8:361-368.

31. Nurberger, T., Brunner, F., Kemmerling, B., and Plater, L. 2004. Innate immunity in plants and animals: Striking similarities and obvious differences. Immunol. Rev. 198:249-266.

32. Pedley, K. F., and Martin, G. B. 2003. Molecular basis of Pto-mediated resistance to bacterial speck disease in tomato. Annu. Rev. Phytopathol. 41:215-243.

33. Pfaffl, M. W. 2001. A new mathematical model for relative quantification in real-time RT-PCR. Nucleic Acids Res. 29:e45.

34. Sambrook, J., Fritsch, E. F., and Maniatis, T. 1989. Molecular Cloning: A Laboratory Manual. Cold Spring Harbor Laboratory, Cold Spring Harbor, NY.

35. Simpson, S. D., Ashford, D. A., Harvey, D. J., and Bowles, D. J. 1998. Short chain oligogalacturonides induce ethylene production and expression of the gene encoding aminocyclopropane 1-carboxylic acid oxidase in tomato plants. Glycobiology 8:579-583.

36. Stork, I., Gartemann, K.-H., Burger, A., and Eichenlaub, R. 2008. A 
family of serine proteases of Clavibacter michiganensis subsp. michiganensis: $\operatorname{chp} C$ plays a role in colonization of the host plant tomato. Mol. Plant Pathol. 9:599-608.

37. Strider, D. L. 1969. Bacterial canker of tomato caused by Corynebacterium michiganense. A literature review and bibliography. North Carolina Agricultural Experimental Station, Tech. Bull. 193.

38. Tyler, B. M. 2009. Entering and breaking: Virulence effector proteins of oomycete plant pathogens. Cell. Microbiol. 11:13-20.

39. Van Alfen, N. K. 1989. Reassessment of plant wilt toxins. Annu. Rev. Phytopathol. 27:533-550.

40. Vandesompele, J., De Preter, K., Pattyn, F., Poppe, B., VanRoy, N., De Paepe, A., and Speleman, F. 2002. Accurate normalization of real-time quantitative RT-PCR data by geometric averaging of multiple internal control genes. Genome Biol. 3(7): research0034.1-0034.11. 